\title{
Knowledge, Attitude and Perception towards the Consumption of Waste Cooking Oil between Suburban and Rural Communities
}

\author{
Hanisah Kamilah ${ }^{\# 1}$, Megat Azlan Azmi* and Tajul Aris Yang ${ }^{\# 2}$ \\ \# Food Technology Division, School of Industrial Technology, Universiti Sains Malaysia, 11800 Penang, Malaysia \\ E-mail: ${ }^{1}$ HanisahKamilah@gmail.com, ${ }^{2}$ taris@usm.my \\ *Environmental Division, School of Industrial Technology, Universiti Sains Malaysia, 11800 Penang, Malaysia \\ E-mail: megatazlanazmi@gmail.com
}

\begin{abstract}
The improper discarding method of toxic waste cooking oil (WCO) and the repetitive usage of it are polluting the environment and harmful to human, respectively. Thus, survey regarding the consumption of waste cooking oil (WCO) was conducted in Kampung Nelayan, Penang (rural area) and Gurun, Kedah (suburban area). Each developed questionnaire containing the total amount of 26 questions, which five open-ended questions and 21 closed questions. Feedbacks of over 180 responses were received from Gurun, Kedah and 200 responses from Kampung Nelayan, Pulau Pinang. Focus group survey and face-to-face interview method were done in Gurun, Kedah and Kampung Nelayan, Pulau Pinang, respectively based on the suitability of the area. Personal information such as race, gender, and occupation of participants was recorded for further information. The percentage of $80 \%$ of the respondents was females and there was higher percentage of housewives (59\%) in Kampung Nelayan compared to Gurun. Majority of the respondents were consuming palm oil $(95 \%)$ and producing waste cooking oil (WCO) up to 6-10 L/mth and $1 \mathrm{~L} / \mathrm{mth}$ in Kampung Nelayan and Gurun, respectively. Survey analysis also showed that $2-3 \%$ of the respondents utilised the cooking oil repeatedly until it is fully utilised. Around $7-9 \%$ of respondents consumed the cooking oil up to three times before discarding it. As the conclusion, most of the respondents have limited knowledge regarding the WCO management, which could affect the health of a consumer and adulterates the environment.
\end{abstract}

Keywords - Survey; waste cooking oil; toxic; pollution; awareness

\section{INTRODUCTION}

The popular interest of fried delicacies among the Malaysian has increased the waste volume of waste cooking oil (WCO). The abundance accumulation of the waste has become a burden, which the discarding process of WCO is not well-managed. In order to dispose the WCO with an easy method, the people tend to discard it via the water-route or water-bodies. As the discarded WCO contacted with water, it will float and accumulated into a thin layer which the oxygen is impermeable to reach the aquatic organisms. Thus, the extinction of marine species and the shortage of food supplies will occur. Besides, as the temperature reduced, the discarded WCO will be solidified and caused blockage to the drainage. This circumstance will lead to disaster such as flood as the drainage system was blocked by the solidified WCO.

Other than that, the consumers tend to re-use the WCO for the saving factor and it is more crucial as it was utilised fully into the cooked gravy. The repeated usage of WCO is harmful to human health as the repeated heat enhances the oxidation process that occurred within the cooking oil. Few other reactions such as hydrolysis or thermal reaction will give the same effect as oxidation, which many types of byproducts will be accumulated in the oil. Once the used oil was utilized again for cooking, these by-product will react with the fried food and end-up transferred into the human bodies. By-products such as polymers, peroxides, aldehydes, ketones, amines or diamines are potential to accumulate in human body and cause diseases such as cancer, high blood pressure, atherosclerosis and others [1,2,3]. Thus, proper management and enhancing programmes of awareness is important to overcome this crucial issue.

In the meantime, the management of WCO needs to be reviewed as there is no proper management that have been organised by the authority. As the WCO were produced by the consumer, the waste is freely to be discarded into the environment based on the decision of the users.

As poor waste management was applied, certain private companies will intend to collect the WCO for the unsure purpose. The WCO will be collected in large scales by the companies from restaurants. As further process, the WCO 
will be deodorised and decolourised to be packed as recycle cooking oil. However, even WCO have been gone through such process, the by-products that were forms are irreversible. In which, it will effects human health in long term period as it will be accumulated in the organs.

Thus, it is suggested that the WCO is collected by the recognised authorities and processed into safer products such as soaps, candle, plastics, or any other value-added purposed. It will be applicable in Malaysia as the production of WCO are vast which are approximately 50, 000 tonnes per year. If the WCO management is properly done, new value-added products can be produced and indirectly possible to contribute to the economy of the country [4].

However, before further steps are taken, the awareness among the communities needs to be fostered, as their cooperation is valuable to make the plan possible. In this study, we present and discuss the results of the survey from two different areas, Kampung Nelayan, Pulau Pinang and Gurun, Kedah, respectively. Kampung Nelayan is located in west peninsular of Malaysia and northwestern part of Penang Island, whilst Gurun, Kedah, is located in North Malaysia. The population is of 39,590 people and 2,624 people for Gurun, Kedah and Kampung Nelayan, Penang, respectively [5]. Study was conducted to evaluate the attitude of cooking oil consumption from the consumer, types of cooking oil, number of repeated usage of WCO, volume of WCO that have been discarded and the discarding method of the consumer. Besides, the diet of the consumers can also be observed. At the end, measures of improvement from the current condition and few identified solutions were suggested.

\section{MATERIALS AND METHODS}

Kampung Nelayan which is located at the coastal area of Penang is known as rural area as the most of the population is employed with fisheries and tourism. The density of population is lower in the area with less building and consists of basic facilities. However, Gurun is classified as suburban area as the place has many buildings but consists of lower density of population. Majority of Gurun communities are employed for industrial or service sectors. Gurun, also have more facilities compared to Kampung Nelayan such as boarding schools, educational institutes, shopping complex, factories, and others. These areas were assessed in a period of two months (June-July 2012).

Survey questions were distributed to a large number of respondents in order to evaluate the attitude of community towards the awareness of WCO management. Questionnaire was developed through a group discussion among members of project and verified by the group leader. Each questionnaire containing a total amount of 26 questions was given to 200 respondents in Gurun, Kedah and 230 respondents in Kampung Nelayan, Pulau Pinang. All questions were designed and filtered based on the suitability of our objectives. There were 5 open-ended questions and 21 closed questions. Feedbacks of over 180 responses were received from Gurun, Kedah and 200 responses from Kampung Nelayan, Pulau Pinang.

Focus group survey and face-to-face interview methods were done in Gurun, Kedah and Kampung Nelayan, Pulau Pinang, respectively. Different methods were applied based on the suitability of the area and to observe the result differences to compare the outcomes. Personal information such as the race, gender, and occupation of participants was recorded for further information [6].

\section{RESULTS AND DISCUSSION}

\section{A. Survey and health assessment of re-using the cooking oil in the community}

Awareness campaign and survey analysis were conducted in two selected locations; they were in: (1) Gurun, Kedah with a population of 39,590 people and (2) Kampung Nelayan, Penang with a population of 2,624 people. The number of population was according to Department of Statistics Malaysia, 2010.

Demographic characteristic of all the respondents are summarised in Table 1. Majority of the respondents are female. The trend was similar for both places. The questionnaire obtained positive response from every race, including Malay, Chinese and Indian. Malay was the major respondents in the analysis of both places. Majority participants aged between 10-20 years old and 41-50 years old, in Gurun and Kampung Nelayan, respectively. This result can be correlated to the age statistic of both places. Gurun was mostly occupied by individual aged between 1020 years old while in Kampung Nelayan, the individuals were mostly 41-50 years old [5].

TABLE I

DEMOGRAPHIC CHARACTERISTICS OF RESPONDENTS

\begin{tabular}{|c|c|c|c|}
\hline \multicolumn{2}{|l|}{ Location } & \multirow{2}{*}{$\begin{array}{c}\text { Gurun } \\
\text { Percentage } \\
(\%)\end{array}$} & \multirow{2}{*}{$\begin{array}{c}\begin{array}{c}\text { Kampung } \\
\text { Nelayan }\end{array} \\
\text { Percentage } \\
(\%) \\
\end{array}$} \\
\hline Demographics & Categories & & \\
\hline \multirow[t]{2}{*}{ Gender } & Male & 24 & 15 \\
\hline & Female & 76 & 86 \\
\hline \multirow[t]{4}{*}{ Race } & Malay & 89 & 89 \\
\hline & Chinese & 7 & 4 \\
\hline & Indian & 3 & 7 \\
\hline & Others & 2 & 1 \\
\hline \multirow[t]{5}{*}{ Age } & $10-20$ & 36 & 6 \\
\hline & $21-30$ & 30 & 13 \\
\hline & $31-40$ & 16 & 17 \\
\hline & $41-50$ & 13 & 47 \\
\hline & $51-60$ & 5 & 18 \\
\hline \multirow[t]{4}{*}{ Occupation } & Housewives & 21 & 59 \\
\hline & Teachers & 30 & 3 \\
\hline & Students & 7 & 8 \\
\hline & Others & 42 & 31 \\
\hline \multirow[t]{2}{*}{ Marital status } & Single & 55 & 14 \\
\hline & Married & 45 & 86 \\
\hline
\end{tabular}

Housewives, teachers and students were among the target groups for the awareness and knowledge transfer campaign. These groups were expected to transfer the knowledge and healthy habit to their family and students. The percentage of married participants was lower in Gurun as compared to that in Kampung Nelayan, which was $45 \%$ and $86 \%$, respectively. This was probably influenced by the availability of job vacancies in Gurun that was mainly occupied with factories, boarding schools, institution, and office [7]. On the other 
hand, Kampung Nelayan is consisted of fishermen, businessmen, teachers, and retirees.

\section{1) The consumption of cooking oil from the respondents}

The survey of this study showed that $90-95 \%$ of the respondents from both places preferred to use palm oil (Figure 1) [8]. This is due to the preference over good flavors, low price, healthy and contains stable carbon chain. Besides, palm oil is appropriate to be used for deep-frying [4]. In addition to palm oil, minority of family members in both communities consumed corn oil, soybean oil, and olive oil.

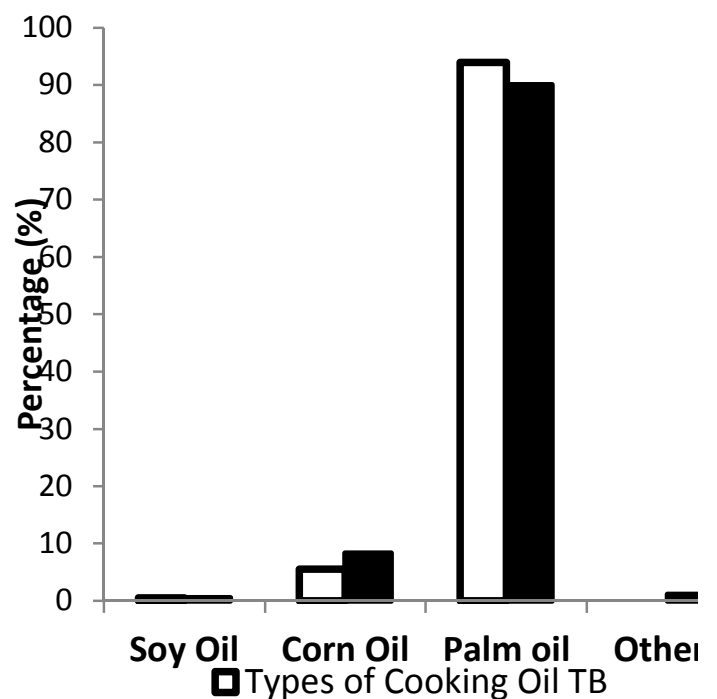

Fig. 1 Types of vegetable oil used by Gurun $(G)$ and Kampung Nelayan (TB) communities

The focus of discussion was narrowed down to the type of brands selected by the participants. Seri Murni palm oil brand was the most popular selected brand in Gurun with a percentage of $34 \%$. Other brands that normally appeared in the form of plastic packet became the main selection (37\%) of Kampung Nelayan's community. The preference of Kampung Nelayan's community over packet oil was due to the effort of community to reduce the capital of their food businesses in Kampung Nelayan. Contrary to Kampung Nelayan, Gurun community was involved in professional career (Table 2) [7]. The source of packet palm oil was doubtful as it is speculated to be re-processed oil. Even though the colour of bleached and filtered used cooking oil looks similar to fresh cooking oil, the by-products shall remain in the re-processed oil [9].

TABLE II

SELECTED COOKING OIL BRAND OF THE RESPONDENTS

\begin{tabular}{|l|c|c|}
\hline Location & Gurun & Kampung Nelayan \\
\hline Brand of Palm Oil & Percentage (\%) & Percentage (\%) \\
\hline Seri Murni & 34 & 30 \\
\hline Saji & 21 & 8 \\
\hline Buruh & 9 & 21 \\
\hline Knife & 4 & 3 \\
\hline Vesawit & 3 & 2 \\
\hline Others & 28 & 37 \\
\hline
\end{tabular}

Further survey revealed that Gurun community had the tendency $(63 \%)$ to consume $1 \mathrm{~L}$ of cooking oil in one month, whilst Kampung Nelayan residents consumed higher volume of oil, which was 6-10 L per month (69\%). This indicated that Kampung Nelayan had a higher tendency of producing more waste cooking oil (Figure 2).
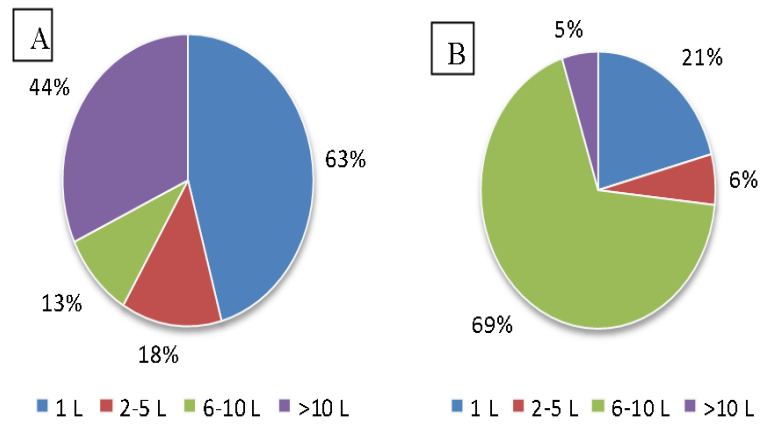

Fig. 2 The volume of cooking oil consumed by the A) Gurun and B) Kampung Nelayan communities

In terms of repeating usage of cooking oil, survey analysis showed that few $(2-3 \%)$ of the respondents utilised the cooking oil repeatedly until finish. Around $7-9 \%$ of respondents consumed the cooking oil up to 3 times before discarding it. They were not aware of the health risk caused by repeating usage of WCO. Majority of the respondents of both places were consumed the cooking oil twice compared to the group that utilizing the WCO repeatedly for one time. The percentages were within $50-60 \%$ and $30-40 \%$ for each of the consumption, respectively (Figure 3 ).

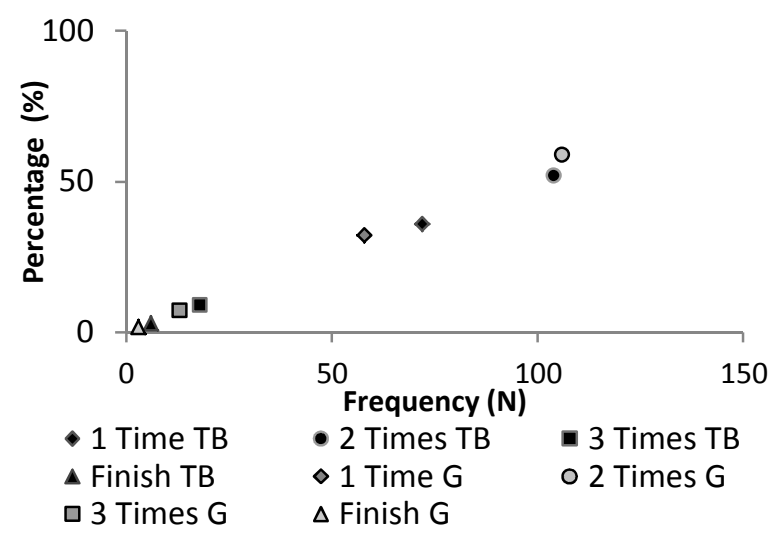

Fig. 3. The number of repeated usage of cooking oil by the respondents

Repeating usage of cooking oil is not encouraged due to the formation of by-products that are formed by the thermal reaction during frying process $[1,2,10,11]$. In normal cooking, the temperature of oil may reach $180{ }^{\circ} \mathrm{C}$. At this temperature, the oxidation reaction, hydrolysis, and thermal reaction produce by-products such as free fatty acids, peroxide, aldehyde, polymers, etc. These compounds post a danger to the consumer's health [12], and different kind of diseases such as asteroschlerosis, heart problem, enlargement of organs and other kind of internal disease may occur [3]. 
TABLE III

DEMOGRAPHIC CHARACTERISTICS OF RESPONDENTS

\begin{tabular}{|c|c|c|c|}
\hline \multicolumn{2}{|l|}{ Location } & \multirow{2}{*}{$\begin{array}{c}\text { Gurun } \\
\begin{array}{c}\text { Percentage } \\
(\%)\end{array} \\
\end{array}$} & \multirow{2}{*}{$\begin{array}{c}\text { Kampung } \\
\text { Nelayan } \\
\begin{array}{c}\text { Percentage } \\
(\%)\end{array} \\
\end{array}$} \\
\hline Details & Categories & & \\
\hline \multirow[t]{4}{*}{ Favourite foods } & Meat & 10 & 4 \\
\hline & Vegetables & 22 & 17 \\
\hline & $\begin{array}{l}\text { Meat and } \\
\text { Vegetables }\end{array}$ & 63 & 60 \\
\hline & Others & 5 & 19 \\
\hline \multirow[t]{2}{*}{ Cooking skill } & Yes & 84 & 94 \\
\hline & No & 16 & 6 \\
\hline \multirow[t]{4}{*}{$\begin{array}{l}\text { Often cooking } \\
\text { skill }\end{array}$} & Grill & 9 & 27 \\
\hline & Steam & 13 & 20 \\
\hline & Fry & 64 & 47 \\
\hline & Boil & 3 & 6 \\
\hline \multirow[t]{5}{*}{$\begin{array}{l}\text { Favourite fried } \\
\text { foods }\end{array}$} & $\begin{array}{l}\text { Banana } \\
\text { fritters }\end{array}$ & 4 & 1 \\
\hline & Fried Fish & 29 & 30 \\
\hline & Fried Egg & 13 & 6 \\
\hline & Fried Chicken & 36 & 48 \\
\hline & Others & 18 & 15 \\
\hline \multirow[t]{4}{*}{ Favourite foods } & Meat & 10 & 4 \\
\hline & Vegetables & 22 & 17 \\
\hline & $\begin{array}{l}\text { Meat and } \\
\text { Vegetables }\end{array}$ & 63 & 60 \\
\hline & Others & 5 & 19 \\
\hline
\end{tabular}

\section{2) Health awareness of the respondents}

In term of health perspective, nearly $80-90 \%$ of the respondents from both sampling locations were aware of healthy diets. The trend was similar to survey result, in which 90-96\% agreed that consuming WCO in large amount is not good for health. The balances $4-10 \%$ of the respondents were consist of teenager's age between 10-20 years old. It is crucial to transfer the knowledge regarding balance diets to this group of respondents as they will influence the lifestyle in future.

Survey also found out that $80-90 \%$ respondents were interested to gain more information about the danger of repeating usage for used cooking oil. About 70-90\% of the respondents had decided to discontinue re-using the cooking oil after the campaign. The percentage was representing both sampling area. Small amount of the respondents preferred to consume the WCO in repetitive manner in a small volume as it will reduce the living cost. This indicates that the respondents need to be advised further regarding the danger of repeated usage of cooking oil.

\section{3) The diets of the communities}

Information regarding the diets of communities reveals the level of healthy-lifestyle of the respondents. Factors such as food selection and cooking method become the primary concern in the survey analysis. Results were summarised in Table 3. It can be observed that both sampling areas preferred to have balanced diet. They had selected meat and vegetables as their favourite food, which was $63 \%$ and $60 \%$, for Gurun and Kampung Nelayan, respectively. Majority of the respondents preferred frying method. Frying is easy to apply besides giving good taste to the food such as fish and chicken.

\section{B. Environmental awareness of the respondents}

When the discarding methods were analysed, $39-40 \%$ of the respondents discarded the WCO into drainage and water sewage. This amount showed the lack of exposure regarding proper way to discard WCO. A proper method is to discard the WCO into dustbin. Higher number of improper drainage method in Gurun community could be attributed to the low level of awareness. Meanwhile, it was shown that half of the respondents in Kampung Nelayan community knew that they had to discard the waste into dustbin (Figure 4).

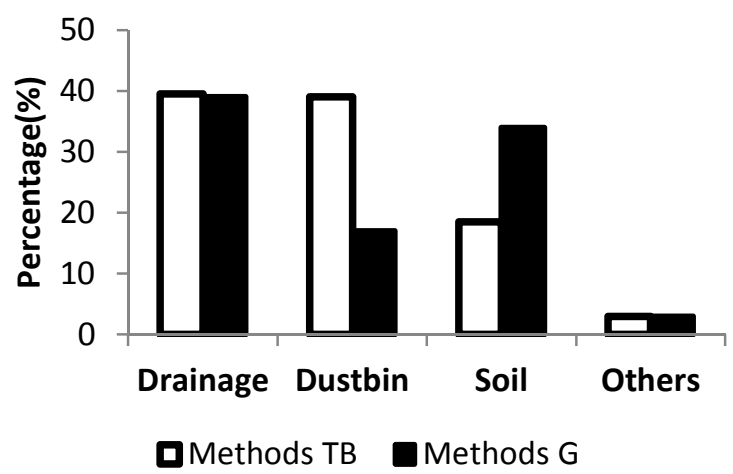

Fig. 4. Method of discarding WCO by respondents' from Gurun and Kampung Nelayan

Discarding WCO into drainage system could cause hazardous effect to the environment. When the temperature in the drainage system decreases, it enhances the solidification of oil and further obstructs the water flow. Further consequences lead to flood and water pollution [13]. Discarding the WCO onto soil changes the soil colour and increases the $\mathrm{pH}$. Other important nutrients in the soil, such as carbon and nitrogen, are reduced as they are prevented to absorb into the soil and affect the presence of aerobe bacteria [14].

Detailed analysis of the questionnaire indicated that 8$16 \%$ from both sampling areas were not aware that the method of discarding WCO had the possibilities to affect and pollute the environment. Few possible solutions were offered to the respondents, and approximately $80 \%$ of the communities agreed to get involved with the service provided by the research team in order to overcome the environmental pollution. The solutions and services suggested were a) The project member collected the WCO from the respondent's house, $b$ ) the respondents were willing to send the WCO to a collection centre, and c) the respondents were given the knowledge and information regarding the WCO. Remaining $20 \%$ of total respondents in both locations did not agree to be involved due to time limitation and distances from the collection centre.

Limited knowledge regarding WCO management could affect the health of consumer and pollutes the environment. This study found that $36 \%$ of Gurun respondents gained the awareness knowledge from the media such as internet while the remaining respondents gained the knowledge via campaign, brochures and questionnaire given by USM (Figure 5). In Kampung Nelayan, $41 \%$ of the respondents gained the awareness knowledge via the television and others, which is from the USM campaign. This showed that 
the campaign and survey had a positive impact to the local residents in term of knowledge and behaviour.

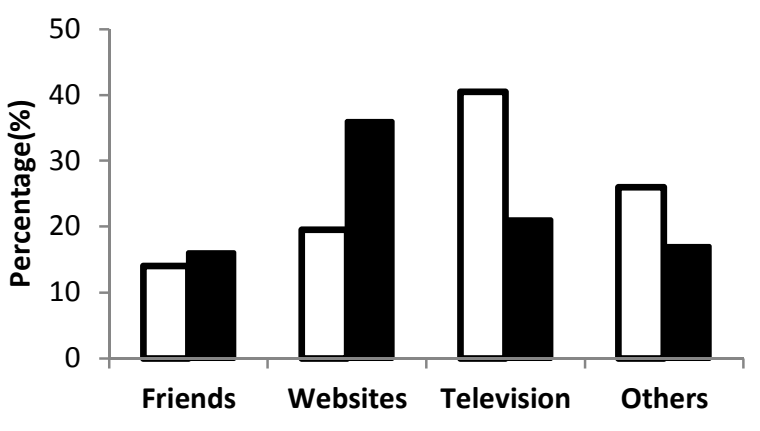

口Information Sources TB Information Sources G

Fig. 5. Information sources of the respondents for Kampung Nelayan and Gurun communities

\section{The cooperation of the respondents}

In order to obtain the cooperation, few points were proposed in objective to be transparent and gain the mutual aid of the communities. The points were a) Utilising the WCO for producing energy and other value-added products b) Education purpose-enhance the awareness of the communities regarding the danger of WCO towards health and environment c) Assist the communities to discard the $\mathrm{WCO}$ in a proper way.

About $14-17 \%$ of the respondents agreed with all the proposed suggestions while $30-33 \%$ agreed to suggestion (a) only. Another $22-27 \%$ and $22-23 \%$ agreed to the suggestion (b) and (c), respectively. Other than that, the respondents suggested that the campaign should be continued further in order to enhance the understanding of the communities regarding WCO. Despite so, the campaign was to increase the promotion of the healthy diet by reducing the consumption of fried food and enhance boiled and grilled food.

\section{CONCLUSIONS}

The awareness campaign received positive response from the targeted communities and more effort shall be made to foster a healthy lifestyle and conserve the environment. The cooperation from the residents and authority will enhance better understanding regarding the danger of WCO to the environment. This survey serves as a tool to measure respondents' awareness, which will be beneficial for further actions.

\section{ACKNOWLEDGMENT}

The authors would like to acknowledge the community of Kampung Nelayan, Pulau Pinang and Gurun, Kedah for the cooperation given during the survey activities. H Kamilah would like to appreciate BJIM grant for the financial support that was provided for the research study.

\section{REFERENCES}

[1] K. Ahmad, Performance of special quality and standard palm olein in batch frying of fish nuggets. Palm Oil Developments, 43, 10-15, 2005.

[2] S. Bastida and F.J.S. Muniz, Thermal oxidation of olive oil, sunflower oil and a mix of both oils during forty discontinuous domestic frying of different foods. Food Science and Technology International, 7(1), 15-21, 2001.

[3] P.W. Sylvester, M. Russel, M.M. Ip and C. Ip, Effects of oil palm phenolics on tumor cells in vitro and in vivo. Cancer Research, 46, 757-758, 1986

[4] K.G. Berger, The use of palm oil in frying. in: Frying oil series, Malaysian Palm Oil Promotion Council, pp. 5-113, 2005.

[5] Department of Statistic, Malaysia, Total population by age group, mukim and state, Malaysia, 2010, (Ed.) Department of Statistic Malaysia. Malaysia, pp. 358-367, 2010.

[6] J. Rattray and M.C. Jones, Essential elements of questionnaire design and development. Journal of Clinical Nursing, 16, 234-243, 2007.

[7] A.A.G Hassan, S.J. Jan, L.H. Eam, The Eff ectiveness of Location Incentive: An Analytical Study of Manufacturing SMEs in the Kedah State. International Journal of Management Studies 16(2), 123-153, 2009.

[8] K. Sundram, R. Sambanthamurthi, and Y.A. Tan, Palm fruit chemistry and nutrition. Asia Pacific Journal of Clinical Nutrition, 12(3), 355-362, 2003.

[9] E. Yilmaz and E. Bulut, Frying Oil Refreshing Capacity of a New Adsorbent Mixture. Academic Food Journal, 10(1), 24-29, 2012.

[10] M. Dubois, G.P. Savage and R.J. Martin, The effect of cooking on the composition and colour of New Zealand grown oca. Food Chemistry, 104, 768-773, 2007.

[11] W.W. Nawar, Chemical Changes in Lipids Produced by Thermal Processing. Journal of Chemical Education, 61(4), 299-302, 1984.

[12] B. Supple, R.H. Hildigi, E.G. Gomez, J.J Leahy, The effect of steam treating waste cooking oil on the yield of methyl ester. Journal of the American Oil Chemists' Society, 2, 175-178., 2002.

[13] M.G. Kulkarni and A.K. Dalai, Waste cooking oil-an economical source for biodiesel: A review. Industrial \& Engineering Chemistry Research 45, 2901-2913, 2006.

[14] D.S. Marjadi and N.A. Dharaiya, Analysis of edible oil contaminated soil within North Gujarat Region. Life Sciences Leaflets, 10, 287-291, 2010 . 